\title{
Relevance of Industrial Wastes from Jatropha curcas L. Seed in Agricultural Biotechnology
}

\author{
Akogwu, R.D. ${ }^{1}$, Aguoru, C.U. ${ }^{2}$, Ikpa, F. ${ }^{3}$, Ogbonna, I. ${ }^{4}$ and Olasan, J.O. ${ }^{2}$
}

\author{
${ }^{1}$ Department of Biological Sciences, Environmental Science and Renewable Energy, University of Agriculture, \\ Makurdi. Nigeria (rakogwu@gmail.com) \\ ${ }^{2}$ Department of Biological Sciences, Plant Science and Biotechnology, University of Agriculture, Makurdi. Nigeria \\ ${ }^{3}$ Department of Biological Sciences, Zoology Unit, University of Agriculture, Makurdi. Nigeria \\ ${ }^{4}$ Department of Biological Sciences, Industrial Microbiology and Biotechnology, University of Agriculture, \\ Makurdi. Nigeria
}

Corresponding authors: Prof. C.U. Aguoru (celeaguoru@yahoo.com); Dr. J.O. Olasan (lekanolasan@yahoo.com); Akogwu, R.D. (rakogwu@gmail.com)

\begin{abstract}
This paper investigated the usefulness of seed cake and husk as industrial wastesgenerated from Jatrophacurcas in biotechnology. Seeds were dehulled, milled and processed for biodiesel production at department of Chemical and Biological Engineering, University at Buffalo, New York, USA.Proximate analysis of the wastes generated (seed husk and cake) was carried out the National Research Institute for Chemical Technology (NARICT) Zaria, Kaduna State, Nigeria. All concentrations were determined using the Microwave Plasma Atomic Emission Spectrophotometer Agilent 4200 (MP-AES) model. Statistical analysis was done on the Minitab software 16.The cake contained 35\% moisture, 17\% ash, $40 \%$ lipid, $70 \%$ protein and $78 \%$ carbohydrate. However, fibre content in husk (27\%) was higher than in cake (16\%). The husk also contained fairly high amount of carbohydrate (47.8\%).Phosphorus was high in both husk and cake ( $17.1 \%$ and $22.3 \%$ respectively). The cake contained higher quantities of micronutrients than the husk with significant differences $(t=2.243, p=0.05)$. The seed cake and husks are rich organic sources of manure as they contain basic nutrients needed by plants to grow. The high amount of protein and carbohydrate makes them perfect candidates as animal feeds when detoxified. From all indicators except in fibre and potassium contents, the seed cake is better than the seed husk. The combined strength and properties of both seed husk and cake should be exploited in Agricultural biotechnology. The two wastes are relevant in both crop and animal production when used as organic manure and animal feeds respectively.
\end{abstract}

Keywords- Agricultural biotechnology, Animal feeds, Industrial waste, Jatrophacurcas, Organic manure.

\section{INTRODUCTION}

Jatrophacurcas L. (family Euphorbiaceae) has recently gained global attention as potential source of biodiesel production(Akogwu, 2011; Nanda et al., 2015). The quest for biofuel as environmentally friendly and renewable energy source is in line with UN goal on climate and the need to ensure safer biosphere that is free from pollutants generated from fossil fuel combustion(Aguoruet al., 2015). Many advanced countries are now cultivating useful plants in large scale for oil and biodiesel production. Jatrophacurcasis particularly of interest today because of its availability, adaptability, ease of cultivation, noninterference with food production and non-edibility (Ouattaraet al., 2018). For this reason, heaps of wastes are generated from the seeds after industrial processing, especially the cake and husks. Burning the wastes would add more to the global $\mathrm{CO}_{2}$ level resulting in enhanced greenhouse effect and climate change(Rathore et al., 2016). Degradation of the recalcitrant husk may take long time thus polluting the environment. Biotechnological conversion of biowastes into useful products is now a welcome development.The aim of this research was to establish the relevance of wastes generated from Jatrophacurcas seed during biodiesel production. The report focused on the proximate analysis and nutritional composition of the seed cake and husks and their potential applications.

\section{MATERIALS AND METHODS}

For the purpose oil and biodiesel production, seeds of Jatrophacurcas were collected from 9 Local Government Areas in Benue State. Seeds were dehulled, milled and processed at department of Chemical and Biological Engineering, University at Buffalo, New York, USA. 
Proximate analysis of the wastes generated including seed husk and cake was carried out the National Research Institute for Chemical Technology (NARICT) Zaria, Kaduna State, Nigeria. Nutritive components, macro and micro-elements were investigated following standard protocols (Adinurani et al., 2015; Sanchez-Arreola et al., 2015). All concentrations were determined in part per million (ppm) using the Microwave Plasma Atomic Emission Spectrophotometer Agilent 4200 (MP-AES) model. Statistical analysis was done on the Minitab software 16.

\section{RESULTS AND DISCUSSION}

Table 1presents seven nutritional composition in the industrial waste investigated in Jatrophaseed. The cake contained $35 \%$ moisture, $17 \%$ ash, $40 \%$ lipid, $70 \%$ protein and $78 \%$ carbohydrate. These components are relatively of higher values in cake than husk. However, fibre content in husk $(27 \%)$ was higher than in cake $(16 \%)$. The husk also contained fairly high amount of carbohydrate (47.8\%). Box plot (Figure 1) revealed significant differences in the nutritional values of the two wastes from Jatropha seeds ( $t=4.092, \quad \mathrm{P}=0.002$ ).Figure 2 shows the macronutrients investigated. Phosphorus was high in both husk and cake ( $17.1 \%$ and $22.3 \%$ respectively). The potassium content of husk $(21.2 \%)$ doubled that of cake $(11 \%)$ but the latter contained more sodium (20.4\%). Among the five microelements studied (Table 2), the iron content recorded the highest values (3.12ppm in husk, 6.66ppm in cake). Other elements $>1 \mathrm{ppm}$ were zinc $(1.98 \mathrm{ppm}$ in cake) and lead (1.62ppm in cake). The cake contained higher quantities of micronutrients than the husk with significant differences $(\mathrm{t}=2.243, \mathrm{p}=0.05)$. Arsenic was present in equal proportion $(0.36 \mathrm{ppm})$. With the exception of copper present in minute quantity in seed husk (0.059 ppm), other micronutrients were present in high quantity which appeared to confer toxicity to the seed.

Table 1: Comparative Nutritional Compositions ofJatrophacurcasSeed Husk and Cake

Jatropha seed cake and husk( $t=4.092, \mathrm{P}=0.002)$

\begin{tabular}{|c|c|c|c|c|c|c|}
\hline & $\begin{array}{c}\text { Moisture } \\
(\boldsymbol{\%})\end{array}$ & $\begin{array}{c}\text { Ash } \\
(\boldsymbol{\%})\end{array}$ & $\begin{array}{c}\text { Lipid } \\
(\boldsymbol{\%})\end{array}$ & $\begin{array}{c}\text { Fiber } \\
(\boldsymbol{\%})\end{array}$ & $\begin{array}{c}\text { Protein } \\
(\boldsymbol{\%})\end{array}$ & $\begin{array}{c}\text { Carbohydrate } \\
(\boldsymbol{\%})\end{array}$ \\
\hline Husk & 11.8 & 6 & 3.2 & 27 & 5 & 47.8 \\
\hline Cake & 35 & 17 & 40 & 16 & 70 & 78 \\
\hline
\end{tabular}

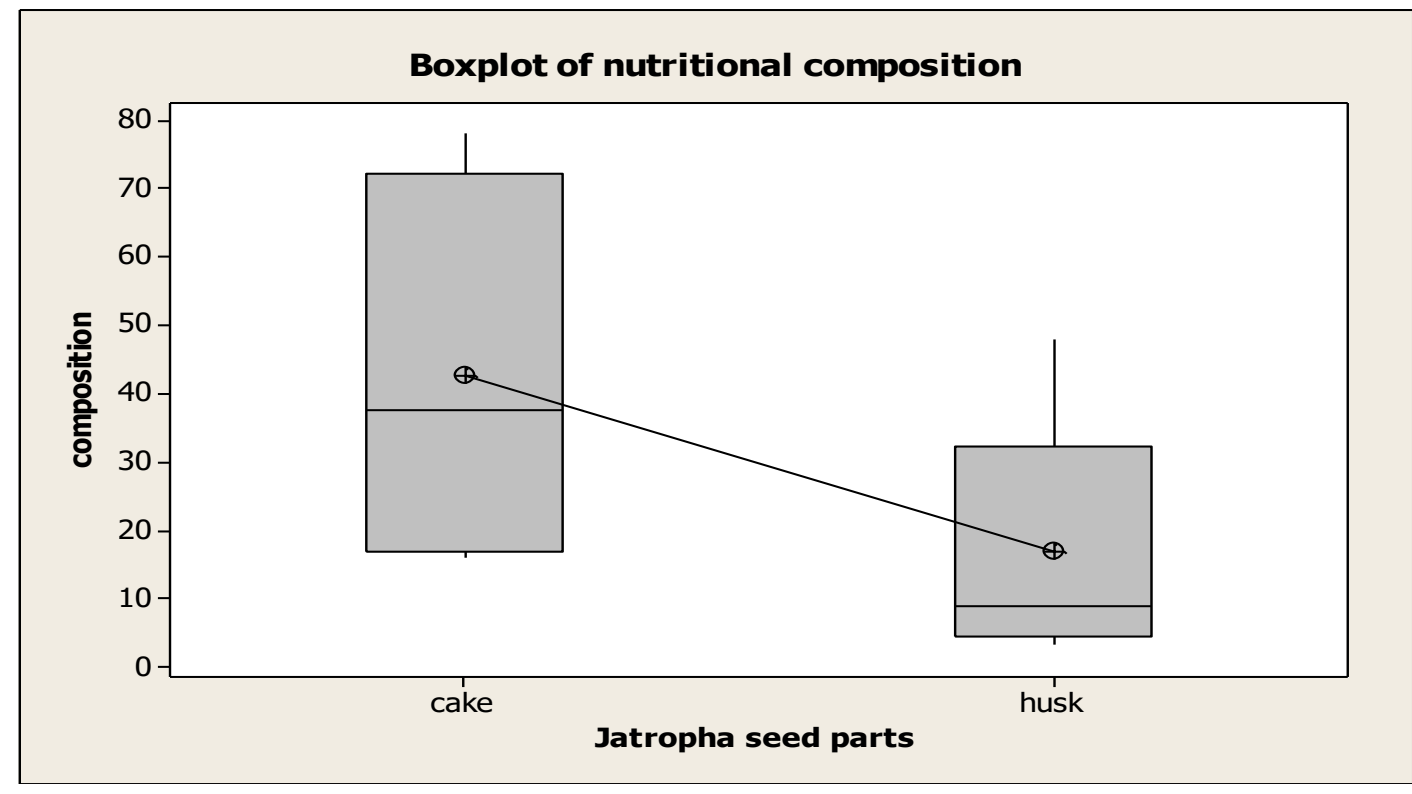

Fig.1: Box plot showing significant differences in nutrient composition in 
- Jatropha Seed Husk $\quad$ Jatropha Seed Cake

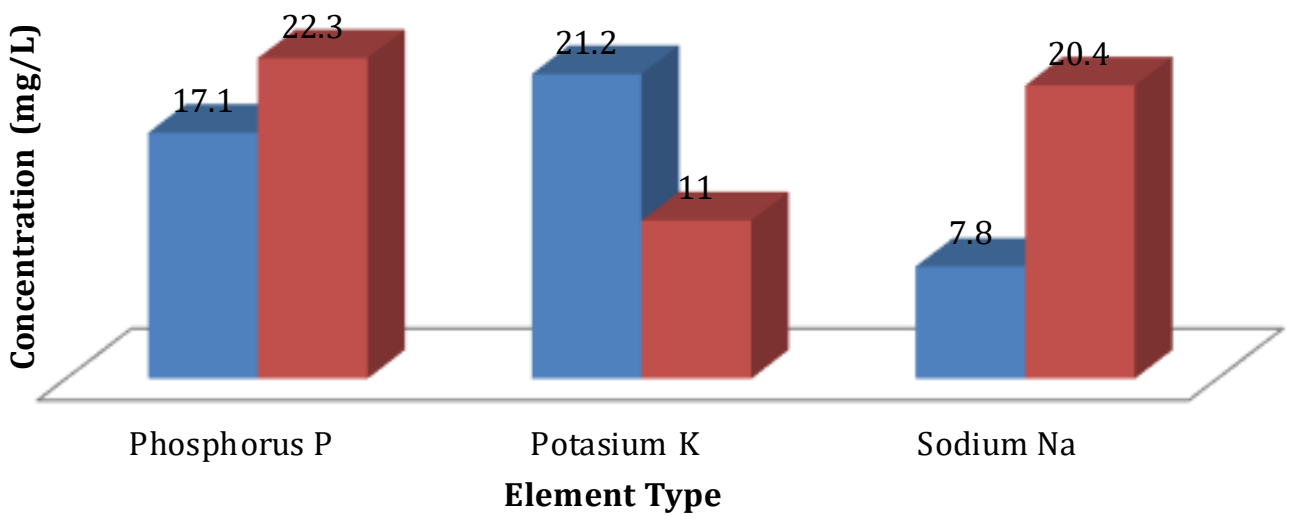

Fig.2: Macronutrients in Jatrophacurcas L Seed Husk and Cake

Table.2: Micro-elements in Jatrophacurcas Seed Husk and Cake

\begin{tabular}{lcc}
\hline Eement (ppm) & Jatrophacurcas Seed Husk & Jatrophacurcas Seed Cake \\
\hline Zinc $(\mathbf{Z n})$ & 0.225 & $\mathbf{1 . 9 8 0}$ \\
Arsenic (As) & 0.360 & 0.360 \\
Copper (Cu) & 0.059 & 0.260 \\
Iron (Fe) & $\mathbf{3 . 1 2 4}$ & $\mathbf{6 . 6 6 4}$ \\
Lead (Pb) & 0.154 & $\mathbf{1 . 6 1 8}$ \\
\hline
\end{tabular}

$(\mathrm{t}=2.243, \mathrm{p}=0.05)$

The seed cake after proximate analysis was found to have very high percentage of protein. This protein content obtained from the present report is far higher than similar report on Jatropha seed cake from India that contained $50 \%$ protein (Nepal et al., 2018). This difference may be attributed to the fact the seeds collected from Benue State is of higher qualitywhich maight be due to the soil fertility and higher amount of rainfall that characterize the climate in the study area (Aye and Haruna, 2018). This view agrees with similar findings that high rate of rainfall and soil fertility are required for better yield and optimum nutritive content in the plant (Matos et al., 2018), although Jatropha as a member of the Euphorbiaceae family can survive under low rainfall.

The outcome of this work strongly recommends Jatropha seed cake and husk asgood source of protein for animal feeds provided the protein can be rendered toxin free (Nepal et al., 2018). The present report agrees with earlier findings that Jatrophaseed cake is an excellent source of protein but it contains some anti-nutritional factors (ANF) that can act as toxins and thus negatively affect the growth and health status of animals (Kromeet al., 2018; Zhao et al., 2018). For instance, the concentrations of arsenic and lead as poisonous heavy metals are quite high in this www.ijeab.com
report.Although toxin content can limit the consumption of Jatrophacurcas seed cake, detoxified Jatrophacurcas protein isolate (DJPI) may be a better option in combating malnutrition most especially in Africa (Musa, et al., 2018; Phuliaet al., 2018).

Apart from high protein content, the cake also contains very high amount of carbohydrates (78\%) of carbohydrate, little amount of lipids, crude fibre and ash. The quantity of iron is quite impressive. Hence, it is recommended as an excellent animal feed if detoxified. Detoxification should target the removal of poisonous lead and arsenic. The agrowaste can also serve as a source of organic manure. This is supported by the high amount of macronutrients such as phosphorus, potassium and sodium present in the seed cake and husk. The present study aligns with the work of Nepal et al. (2018) where basic nutrients were reported in the seed cake and husk. In the proximate analysis and mineral composition of seeds of Jatrophacurcas from Pankshin Local Government Area of Plateau State (Maguet al. 2018), the percentages of micro, macronutrients and minerals contained in the cake and husk were smaller compared to the present findings. 
From the above findings, the agricultural benefits of Jatrophaplant are enormous. The plant can also be intercropped with many cash crops such as coffee, sugar, fruits and vegetables with the Jatrophacurcasoffering both fertilizer and protection against livestock. Jatrophacurcas needs at least $60 \mathrm{~mm}$ of rain annually to thrive however it can survive three years of drought by dropping its leaves. Jatrophais excellent at preventing soil erosion, and the leaves it drops act as a wonderful soil enriching mulch (Baumertet al., 2018).The present report is in line with the work of Aguoruand Okibe(2015)where potential environmental pollutants were bioconverted into useful industrial products of global economic value.It also aligns with previous studies where Jatropha seeds had significant effects in the production of Clariasgariepinus fingerlings (Musa et al., 2008).

In conclusion, the seed cake and husks as agrowaste are rich organic sources of manure as it contains basic nutrients needed by plants to grow. The high amount of protein and carbohydrate makes the agrowaste perfect candidates as animal feeds when detoxified.From all indicators except in fibre and potassium contents, the seed cake is better than the seed husk. Thecombined strength and properties of both seed husk and cake as highlighted above should be exploited in Agricultural biotechnology. The two wastes are relevant in both crop and animal production when used as organic manure and animal feeds respectively.

\section{REFERENCES}

[1] Adinurani, P. G., Hendroko, S. R., Nindita, A., Wahono, S., Maizirwan, M., Sasmito, A., et al. (2015). Chaterization of Jatrophacurcas Linn. Capsule Husk as Feedstock for Anaerobic Digestion. Energy Procedia, 65, 264-273.

[2] Aguoru, C. U., Azua, E.T. Olasan, O.J.(2015)Approaches to minimizing and overcoming current biodiversity loss. British Journal of Environmental Sciences, 3(3):12-26

[3] Aguoru, C. U., Okibe, P. O.(2015). Content and composition of lipid produced by chlorella vulgaris for biodiesel production. Advances in Life Science and Technology, 36:96-100

[4] Akogwu, R. D. (2011). The viability of biodiesel production in Nigeria using Jatropha curcas as a feedstock. Msc Thesis. Department of Energy and Environmental Management. University of Abertay Dundee UK.

[5] Aye, G. C. and Haruna, R. F. (2018). Effect of Climate Change on Crop Productivity and Prices in Benue State, Nigeria: Implications for Food Security.
Establishing Food Security and Alternatives to International Trade in Emerging Economies, 244:268.

[6] Baumert, S., Khamzina, A., \& Vlek, P. L. (2018). Greenhouse gas and energy balance of Jatropha biofuel production systems of Burkina Faso. Energy for Sustainable Development, 42, 14:23.

[7] Krome, C., Jauncey, K., Lohaus, G., \& Focken, U. (2018). Phytate analysis and phytase application in Jatropha curcas kernel meal for use in aquaculture feeds. Aquaculture, Aquarium, Conservation \& Legislation, 11 (3), 690:700.

[8] Magu Thomas Odey, Louis Hitler, Nzeata-Ibe Nelson . (2018) Proximate Analysis and Mineral Composition of Jatrophacurcas Seeds Obtained from Pankshin Local Government Area of Plateau State of Nigeria, $J$ Phys Chem Biophys, 8:1

[9] Matos, F. S., Ciappina, A. L., Rocha, E. C., and Almeida, L. M. (2018). Factors that influence in Jatropha curcas L. latex production. Bragantia, 77(1), 74:82.

[10] Musa, S. O., Tiamiyu, L. O., Solomon, S. G., Ayuba, V. O., \& Okomoda, V. T. (2018). Nutritional value of hydrothermally processed Jatropha curcas kernel and its effect on growth and hematological parameters of Clarias gariepinus fingerlings (Burchell, 1822). Aquaculture Reports, 10, 32:38.

[11] Nanda, S., Azargohar, R., Dalai, A. K., and Kozinski, J. A. (2015). An assessment on the sustainability of lignocellulosic biomass for biorefining. Renewable and Sustainable Energy Reviews, 50, 925-941.

[12] Nepal, S., Kumar, V., Makkar, H.P.S. (2018). Comparative nutritional value of Jatrophacurcas protein isolate and soy protein isolate in common carpFish Physiology andBiochemical Journal, 44: 143.

[13] Ouattara, B., Diédhiou, I., Belko, N., \& Cissé, N. (2018). Growth and Transpiration of Jatropha curcas L. Seedlings under Natural Atmospheric Vapour Pressure Deficit and Progressive Soil Drying in SemiArid Climate. Agricultural Sciences, 9(06), 639.

[14] Phulia, V., Sardar, P., Sahu, N. P., Sanap, B. N., Shamna, N., Fawole, F. J. and Gupta, S. (2018). Effect ofDetoxification Methods on Anti-nutritional Factors and Proximate Composition of Defatted Jatropha curcas Kernel Meal. Animal Nutrition and Feed Technology, 18(1), 67:77.

[15] Rathore, D., Nizami, A.-S., Singh, A., and Pant, D. (2016). Key issues in estimating energy and greenhouse gas savings of biofuels: challenges and perspectives. Biofuel Research Journal, 3(2), 380-393. 
[16] Sanchez-Arreola, E., Martin-Torres, G., Lozada-

Ramírez, J. D., Hernández, L. R., Bandala-González,

E. R., and Bach, H. (2015). Biodiesel production and de-oiled seed cake nutritional values of a Mexican

edible Jatrophacurcas. Renewable Energy, 76, 143:147.

[17] Zhao, Y., Wang, Y., Wang, H., Wu, Y., Makkar, H. P. and Liu, J. (2018). Nutritional value of detoxified Jatropha curcas seed cake protein isolates using rats as an animal model. Animal Nutrition. 